\title{
The importance of physical fitness for pencak silat athletes: Home-based weight training tabata and circuit can it work?
}

\author{
Ihsan Abdul Patah ${ }^{1, *}{ }^{(}$, Hasanuddin Jumareng $^{2}{ }^{\oplus}$, Edi Setiawan $^{1}{ }^{\oplus}$, \\ Mela Aryani ${ }^{1}$, Ruslan Abdul Gani ${ }^{3}$ \\ Universitas Suryakancana, Indonesia ${ }^{1}$ \\ Universitas Halu Oleo, Indonesia ${ }^{2}$ \\ Universitas Singaperbangsa Karawang, Indonesia ${ }^{3}$
}

Received: 05 January 2021; Accepted 01 February 2021; Published 22 February 2021

Ed 2021; 6(1): 86-97

\begin{abstract}
During the Covid-19 pandemic, pencak silat athletes experienced difficulty improving physical fitness because training could not be done together with a coach, so their physical fitness decreased significantly. This study aimed to test Tabata and Circuit's effectiveness to improve female Pencak silat athletes' physical fitness. This research was quantitative with experimental methods. The subject of this research consisted of Female Pencak silat athletes with low physical fitness levels $(n=20)$. All subjects were randomly allocated to experiment $I$ of the Tabata weight training (TWT) $(n=10)$ and experiment II of the Circuit weight training $(C W T)(n=10)$. The results showed that the physical training such as arm muscle strength $(t=11.00 ; P<0.05)$, leg muscle strength $(t=$ 7.900; $P<0.05)$, muscle endurance $(t=6.014 ; P<0.05)$, flexibility $(t=10.34 ; P<0.05)$, endurance VO2max $(t=$ $17.39 ; P<0.05)$ and power $(t=19.20 ; P<0.05)$, increased significantly due to the intervention of Tabata weight training. A similar increase occurred in Circuit weight training, physical fitness components, such as arm muscle strength ( $t=4.910 ; P<0.05)$, leg muscle strength $(t=12.230 ; P<0.05)$, muscle endurance $(t=4.792 ; P<0.05)$, flexibility $(t=6.107 ; P<0.05)$, endurance VO2max $(t=5.533 ; P<0.05)$ and power $(t=5.982 ; P<0.05)$ increased significantly. Home-based weight training between Tabata and Circuit positively improved the physical fitness of female Pencak silat athletes. This research contributes knowledge in coaching so that lecturers and coaches can use it to improve aspects of athlete's physical fitness.
\end{abstract}

Keywords: Physical fitness; tabata; circuit

https://doi.org/10.25299/sportarea.2021.vol6(1).6172

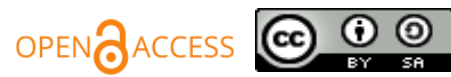

Copyright (C) 2021 Ihsan Abdul Patah, Hasanuddin Jumareng, Edi Setiawan, Mela Aryani, Ruslan Abdul Gani

Corresponding author: Ihsan Abdul Patah, Physical Education Health and Recreation, Universitas Suryakancana, Cianjur, Jawa Barat, Indonesia

Email: ihsan@unsur.ac.id

How To Cite: Patah, I. A., Jumareng, H., Setiawan, E., Aryani, M., \& Gani, R. A. (2021). The importance of physical fitness for pencak silat athletes: Home-based weight training tabata and circuit can it work?. Journal Sport Area, 6(1), 86-97. https://doi.org/10.25299/sportarea.2021.vol6(1).6172

\section{INTRODUCTION}

Martial arts throughout the world has grown rapidly, many martial arts have sprung up, such as Mixed martial arts (MMA), Wing Chun, Krav maga, Karate, Judo, Kungfu, Tai Chi, Shorinji Kempo, Brazilian Jiujitsu, Taekwondo, Muay Thai and Pencak Silat. These martial arts have unique and different stance characteristics (Tack, 2013). Pencak silat, one of the martial arts, grows rapidly in several regions in Indonesia (Kartomi, 2011). Pencak silat matches are carried out in three rounds, the average heart rate of athletes reaching $80 \%$ of MHR, hence pencak silat is high intensity sport (Nugroho, 2020). Pencak Silat 
athlete ought to have good physical fitness (Saputra, Mulyana, Komarudin \& Sartono, 2017), to make the basic techniques of hit, kick and slash can be performed optimally. Physical fitness has a definition as a set of attributes related to a person's ability to do physical activities or sport (Roth et al., 2019), such as cardiorespiratory endurance, strength, flexibility, speed, and power (Lee, Kim, \& Jeon, 2018; Setiawan, Budiarto, Afriyuandi, 2020). Physical fitness has been claimed to be one of the factors to support athletes' performance during training and competition (Saputra et al., 2017). Based on the results of previous studies, it was reported that if physical fitness is not continuously trained it will experience a significant decrease (Vassilis, Yiannis, Athanasios, Dimitrios, Ioannis, \& Thomas, 2019). Some studies showed the decrease in physical fitness after 8 to 12 weeks of inactivity (Ingle, Sleap, \& Tolfrey, 2006). Therefore improving physical fitness is not an easy task for the current era, therefore, we need the training method (Tabata and Circuit) that can be used by athletes anytime and anywhere (e.g., home, indoor/outdoor).

Tabata is an exercise that combines intermittent and high-intensity (Joo, 2015). Tabata is a four minute interval training consisting of 8 rounds of work maximally for 20 seconds, each training is followed by 10 seconds of rest (Sumpena \& Sidik, 2017; Setiawan et al., 2020). Furthermore, Tabata training can also be applied in 20 to 60 minutes (Rýzková, Labudová, Grznár, \& Šmída, 2018). Tabata cannot be applied too often, it is recommended once or twice a week, or 3 days a week (Batacan Jr, Duncan, Dalbo, Tucker, \& Fenning, 2017). The previous study showed that Tabata training is less pleasant or eliminates the pleasure in exercising (Foster et al., 2015). Other studies report that Tabata training is seldom used to improve physical condition because some trainers do not know the benefits of this exercise and still doubt the effectiveness of Tabata training (Sumpena \& Sidik, 2017). In addition, a recent study on Tabata training reports that Tabaat training does not have an effect on muscle strength (Setiawan et al., 2020). Consequently, this research is important to be performed as a way to uncover the issue. Moreover, some studies about Tabata only focused on increasing $\mathrm{VO}_{2 \max }$ (Greenlee et al., 2017) and reducing obesity rates (Khammassi, Ouerghi, Hadj-Taieb, Feki, Thivel, \& Bouassida, 2018; Gerosa-Neto et al., 2016), normalizing hyperglycemia in type 2 diabetic females (Ahmad, 2019). However, there is little literature that discusses Tabata with the physical fitness of pencak silat athletes, so this research is important to do.

Circuit training has a definition as an exercise by involving a series of different exercises at each post that is carried out sequentially and continuously for one turn. Circuit training-combines resistance training and high-intensity. Circuit training can be done with gymnastics, handheld weights, exercise machines, where the posts used are usually from 5 to 8 posts and exercises at each post that is carried out less than one minute (e.g. 15-40 seconds), 20 seconds to rest in each post (Kim et al., 2018). Then the duration of the Circuit exercise is around 20 to 35 minutes (Plevková \& Peráčková, 2019) and some of the training is around 50 to 60 minutes each time (Kim \& Lee, 2019). Previous research has found that Circuit training can increase muscle strength (Wilke et al., 2019), and can increase mobility and stamina (Yadav \& Sardar, 2017). Some studies have examined Circuit training that combining Circuit training with machine for increasing muscle strength and body composition (Lehnert, Stastny, Sigmund, Xaverova, Hubnerova, \& Kostrzewa, 2015), then used Circuit training to improve the body image of primary school girls (Plevková \& Peráčková, 2019).

Although there have been many studies on Tabata and Circuit training, however there are no studies that report the influence of Tabata and Circuit on the physical fitness of pencak silat athletes. In addition, previous studies only examined the effects of each training separately not comparing the training simultaneously. The addition of Tabata and Circuit groups is supposed to improve the physical fitness component. This study aimed to examine the effectiveness of both exercises between Tabata and Circuit to improve the physical fitness of Female athletes of pencak silat. The urgency of this research has an impact on science in the field of training methods, so that later coaches and athletes can use the Tabata and Circuit to increase their physical fitness level, even when they are at home.

\section{METHODS}

\section{Subject}

Twenty Female pencak silat athletes with low level of physical fitness became the subjects of this study. The sampling technique used was purposive sampling by determining the criteria for low levels of physical 
fitness in athletes. All voluntary subjects were randomly allocated to experiment of the Tabata weight training (TWT) $(n=10)$ and experiment II of the Circuit weight training (CWT) $(n=10)$ (see Table 1). Before starting the study, subjects were informed about the study orally and then submitted their written informed consent to the researchers. This research was conducted ethically in according to international guidelines. All participants lived in a city located in the West Java (Indonesia).

Table 1. The Characteristics of The Subjects

\begin{tabular}{lccc}
\hline Group $(\mathbf{n}=\mathbf{2 0})$ & Age (yr) & Height (cm) & Weight (kg) \\
\hline TWT $(\mathrm{n}=10)$ & $20.60 \pm 1.1$ & $1.72 \pm 2.5$ & $60.20 \pm 2.7$ \\
CWT $(\mathrm{n}-10)$ & $20.00 \pm 1.5$ & $1.73 \pm 1.5$ & $59.80 \pm 1.4$ \\
\hline
\end{tabular}

Values are presented as mean \pm standard deviation.

TWT=Tabata weight training; CWT=Circuit weight training; $\mathrm{n}=$ Subjects.

\section{Tabata weight training program}

Tabata weight training was done 3 times a week on Tuesdays, Thursdays and Saturdays. Subject moved to Tabata weight training, consisting of 20 seconds for one exercise with 10 seconds intervals (e.g., running on the spot for 20 seconds, and rest for 10 seconds; squat for 20 seconds, and rest 10 seconds, and so on). This cycle was repeated from 2 until 3 sets, total 4 minutes of workout (see Table 2).

Table 2. Tabata Weight Training Program

\begin{tabular}{|c|c|c|c|}
\hline Training component & Exercise activities & Duration & Itensity \\
\hline Warm-up & $\begin{array}{l}\text { Proprioceptive neuromuscular facilitation (PNF) } \\
\text { and jogging. }\end{array}$ & $10 \mathrm{~min}$ & $\begin{array}{l}40-50 \% \\
\text { HRmax }\end{array}$ \\
\hline Focus on practice & $\begin{array}{l}\text { Tabata workouts } 3 \text { sets of } 20 \text { seconds high } \\
\text { intensity training (e.g., running on the spot, } \\
\text { squat, jumping jack, dumbbell, jack knife, high } \\
\text { knee with load on the leg, plank with load on the } \\
\text { arm, mt. climber), and } 10 \text { seconds of rest. }\end{array}$ & $5 \mathrm{~min}$ & $\begin{array}{l}70-90 \% \\
\text { HRmax }\end{array}$ \\
\hline Cool-down & Stretching. & $10 \mathrm{~min}$ & $\begin{array}{c}40-50 \% \\
\text { HRmax }\end{array}$ \\
\hline
\end{tabular}

\section{Circuit weight training program}

In this study the authors applied the Circuit weight training program 3 times a week (Tuesdays, Thursdays and Saturdays) for 12 weeks with 40 minutes. All subjects post 1 dumbbell, post 2 sprint 2 meters, post 3 push up diamond, etc (See Table 3).

Table 3. Circuit Weight Training Program

\begin{tabular}{|c|c|c|c|}
\hline Training Component & Training Activities & Duration & Itensity \\
\hline Warm-up & $\begin{array}{l}\text { Dynamic and } \\
\text { static stretching }\end{array}$ & $5 \mathrm{~min}$ & $\begin{array}{l}40-50 \% \\
\text { HRmax }\end{array}$ \\
\hline Focus on practice & $\begin{array}{l}\text { Circuit workouts (posts 1: jogging, pos 2: dumbbell, } \\
\text { posts 3: sprint distances } 2 \text { meters with load on the } \\
\text { arm, posts } 4 \text { : push-up diamond with load on the arm, } \\
\text { posts 5: Lunges with body weight, posts } 6 \text { : pull up, } \\
\text { pos 7: squat jumps). }\end{array}$ & $30 \mathrm{~min}$ & $\begin{array}{l}70-90 \% \\
\text { HRmax }\end{array}$ \\
\hline Cool-down & Stretching. & $5 \mathrm{~min}$ & $\begin{array}{l}40-50 \% \\
\text { HRmax }\end{array}$ \\
\hline
\end{tabular}

\section{Procedure}

The study was conducted for 3 months started June until August, 2020 (12 weeks) and approved by the local ethics committee Suryakancana University (approve date 06.05.2020 number: E-20-114-2020) and was carried out according to the Helsinki declaration criteria (e.g. its basic principle is respect for the individual, the right to give consent after obtaining an explanation of involvement in the research, the safety of the subject must always take precedence over the 
interests of science) (Jumareng, Setiawan, Patah, Aryani, Asmuddin, \& Gani, 2021). Subjects of this study was the program Tabata and Circuit weight training in home of each athlete and monitored by the researcher through zoom meeting, for example, researchers observe subjects doing Tabata and Circuit weight training through zoom meetings from the beginning to the end of the activity, this is done in order to prevent transmission of COVID-19. The study was conducted by following the standard COVID-19 protocol, for example, check the body temperature first, then give a Hand sanitizer.

\section{Measure}

We measure physical fitness related to arm muscle strength was measured with a hand grip strength (Takei T.K.K. 5401 Grip-D Tokyo, Japan) (Kim et al., 2018). This test can measure the static strength of the hand muscles. This test has a face validity and reliability of 0.90 . Leg muscle strength was measured with a leg dynamometer (Takei T.K.K. 5402 Back-D Tokyo, Japan), This test has a validity level of 0.60 and a reliability of 0.65 . Muscle endurance was measured for $60 \mathrm{sec}$ using sit up. This test has a face validity level and a reliability level of 0.91 . Flexibility was examined using sit and reach. This test has a face validity and reliability of 0.92 . Endurance $\mathrm{VO}_{2 \max }$ was evaluated by multistage fitness test and. This test has a validity level of 0.92 and a reliability of 0.96 . Power was examined using medicine ball throw test. This test has a validity level of 0.77 and a reliability of 0.84 .

\section{Statistical analysis}

The data were analyzed using IBM SPSS Statistics 25.0. Analysis differences in physical fitness before and after program intervention, we used paired sample t-tests. All values were expressed as mean \pm standard deviation. $P<0.05$ was considered significant (Kim et al., 2018).

\section{RESULTS AND DISCUSSIONS}

The results of this study showed that the physical training of pencak silat Female athletes increased significantly because of the intervention of Tabata weight training. Components of physical fitness, such as arm muscle strength (hand grip strength) $(t=11.00 ; P<0.05)$, leg muscle strength (leg dynamometer) $(t=$ 7.900; $P<0.05)$, muscle endurance (sit up) $(t=6.014 ; P<0.05)$, flexibility (sit and reach) $(t=10.34 ; P<0.05)$, endurance $\mathrm{VO}_{2 \max }$ (multistage fitness) $(t=17.39 ; P<0.05)$ and power (medicine ball throw) $(t=19.20$; $P<0.05$ ), the data showed an increase in all components of physical fitness (see Table 4), the change in values between the pre-test and post-test all components of physical fitness in Tabata weight training as seen in Figure 1.

Table 4. The Result for Physical Fitness Tabata Weight Training

\begin{tabular}{lcccc}
\hline Variable Physical Fitness & Pre & Post & t & $\boldsymbol{P}$-value \\
\hline Arm Muscle Strength & $33.20 \pm 2.5$ & $48.60 \pm 2.0$ & 11.00 & $0.000^{*}$ \\
Leg Muscle Strength & $28.80 \pm 3.7$ & $46.00 \pm 5.3$ & 7.900 & $0.001^{*}$ \\
Muscle Endurance & $22.20 \pm 1.9$ & $31.40 \pm 2.8$ & 6.014 & $0.004^{*}$ \\
Flexibility & $5.40 \pm 5.4$ & $13.80 \pm 1.9$ & 10.34 & $0.000^{*}$ \\
Endurance & $32.14 \pm 2.8$ & $64.09 \pm 2.2$ & 17.39 & $0.000^{*}$ \\
Power & $10.40 \pm 6.1$ & $21.60 \pm 2.0$ & 19.20 & $0.000^{*}$ \\
\hline
\end{tabular}

Values are mean \pm standard deviation. $* P$-value $<0.05$
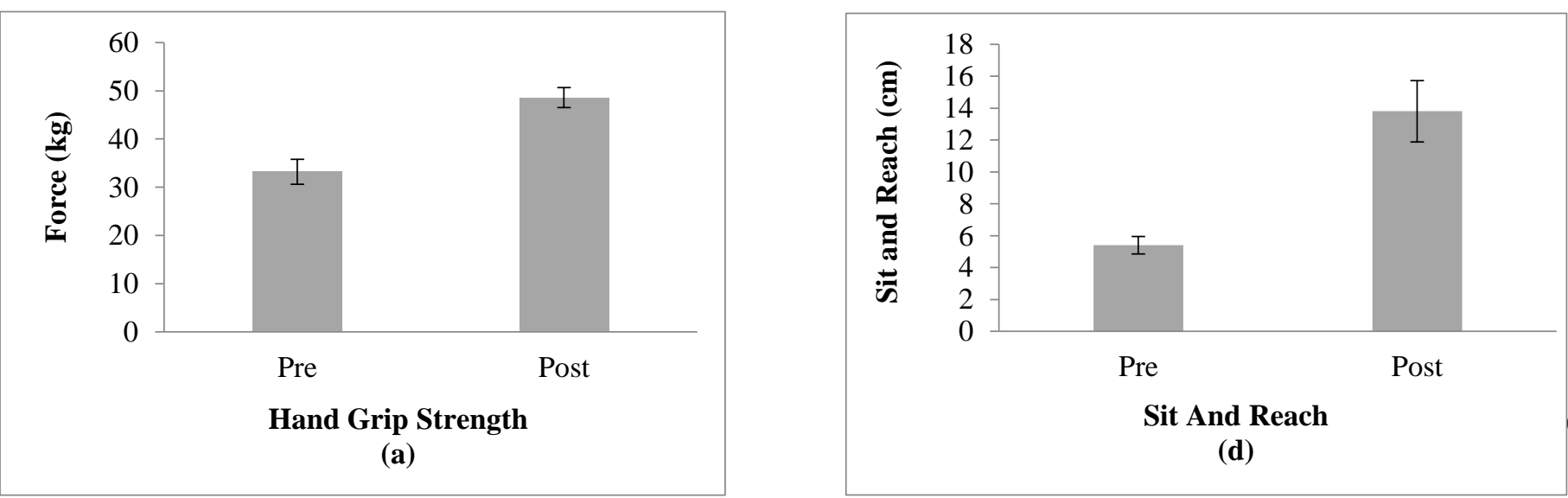

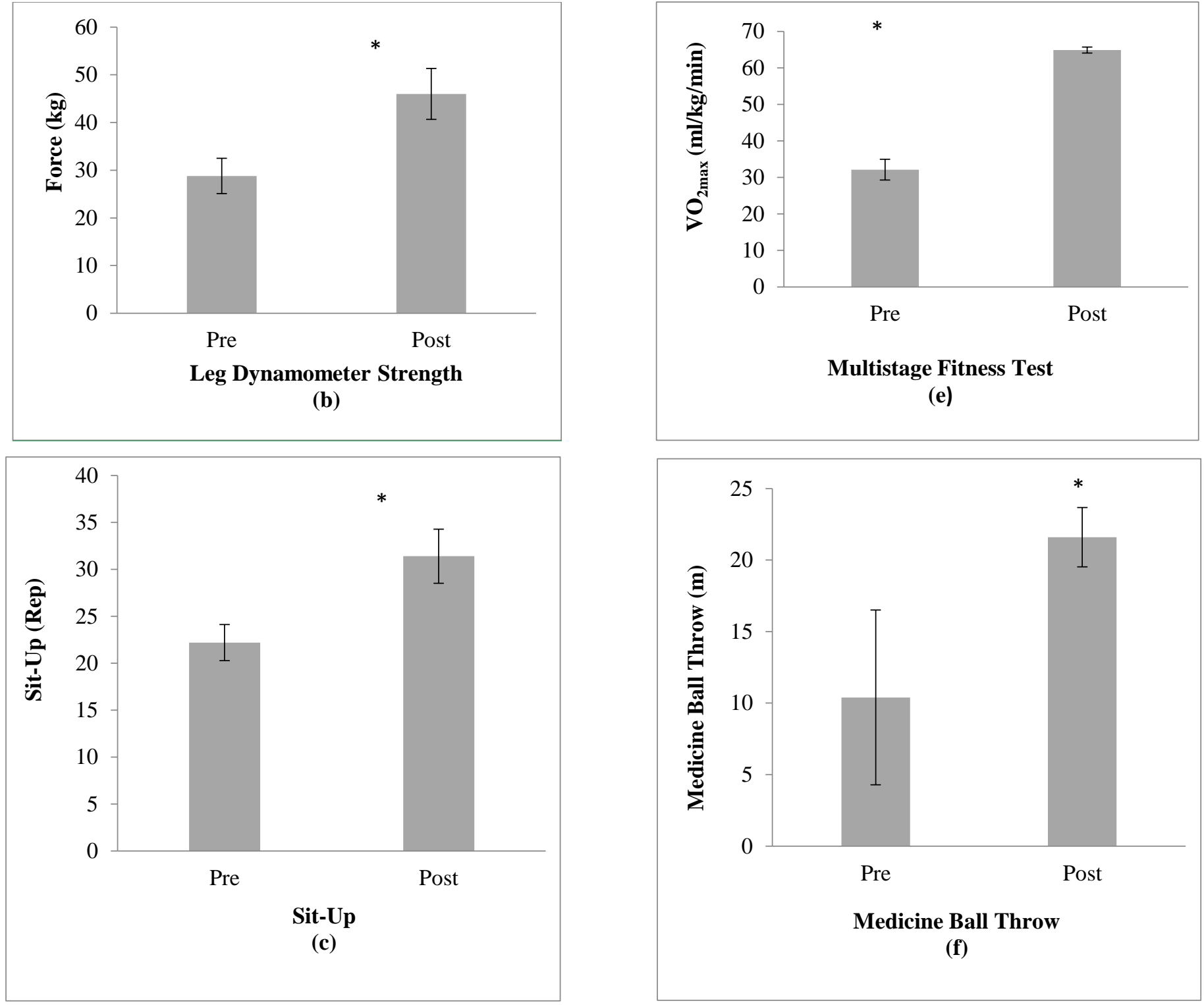

Figure 1.Changes of Hand Grip Strength (HGS) (a), Leg Dynamometer (LD) (b), Sit Up (SU) (c), Sit And Reach (SAR) (d), Multistage Fitness (MF) (e), Medicine Ball Throw (MBT) (f), pre and post 12 weeks of TWT. Significance level was set at $* P$-value $<0.05$.

A similar increase occurred in Circuit weight training, physical fitness components, such as arm muscle strength (hand grip strength) $(t=4.910 ; P<0.05)$, leg muscle strength (leg dynamometer) $(t=12.230$; $P<0.05)$, muscle endurance (sit up) $(t=4.792 ; P<0.05)$, flexibility (sit and reach) $(t=6.107 ; P<0.05)$, endurance $\mathrm{VO}_{2 \max }$ (multistage fitness) $(t=5.533 ; P<0.05)$ and power (medicine ball throw) $(t=5.982$; $P<0.05$ ) (see Table 5). While the change in values between pre-test and post-test all components of physical fitness in the circuit weight training can be seen in Figure 2.

Table 5. The Result For Physical Fitness Circuit Weight Training

\begin{tabular}{lcccc}
\hline Variable Physical Fitness & Pre & Post & t & $\boldsymbol{P}$-value \\
\hline Arm Muscle Strength & $33.40 \pm 4.2$ & $50.80 \pm 4.2$ & 4.910 & $0.008^{*}$ \\
Leg Muscle Strength & $26.80 \pm 3.7$ & $53.20 \pm 4.6$ & 12.230 & $0.000^{*}$ \\
Muscle Endurance & $21.00 \pm 2.3$ & $35.80 \pm 5.2$ & 4.792 & $0.009^{*}$ \\
Flexibility & $5.60 \pm 5.4$ & $12.40 \pm 2.5$ & 6.107 & $0.004^{*}$ \\
Endurance & $32.28 \pm 2.5$ & $52.20 \pm 10.2$ & 5.533 & $0.005^{*}$ \\
Power & $8.40 \pm 1.6$ & $14.20 \pm 8.4$ & 5.982 & $0.004 *$ \\
\hline
\end{tabular}



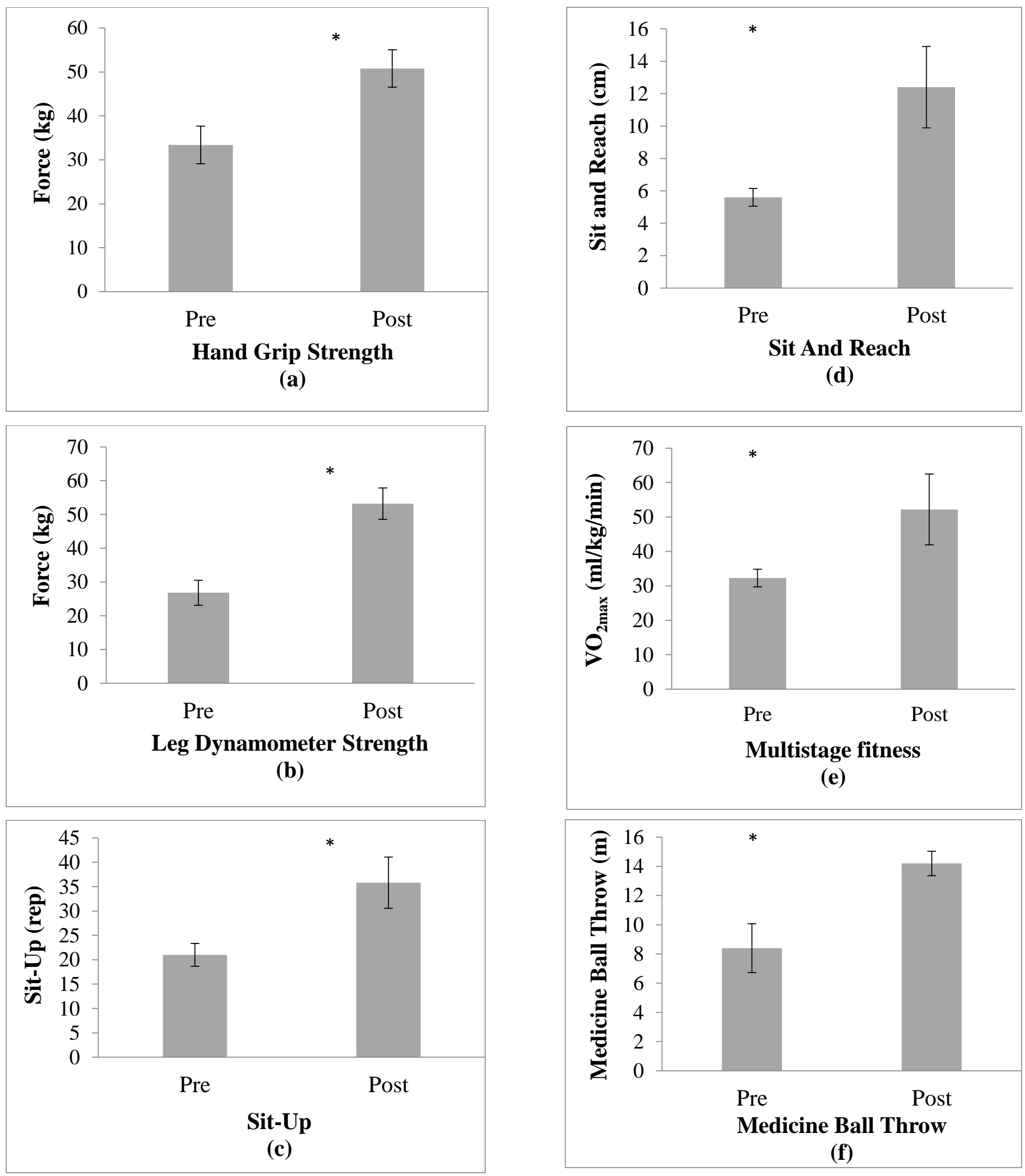

Figure 2. Changes of Hand Grip Strength (HGS) (a), Leg Dynamometer (LD) (b), Sit Up (SU) (c), Sit And Reach (SAR) (d), Multistage Fitness (MF) (e), Medicine Ball Throw (MBT) (f), pre and post 12 weeks of CWT. Significance level was set at $* P$-value $<05$. 
The purpose of our study was to assess the effectiveness of tabata and circuit weight training on improving physical fitness.

\section{The Effects of Tabata Weight Training on Physical Fitness}

Muscle strength is a physical fitness component needed by athletes during the competition (Akınoğlu \& Kocahan, 2018). The results of this study report that 12 weeks of Tabata weight training can significantly increase muscle strength in the legs and arms. The increase that occurs in the muscle of the arms and legs is due to the combined effect of Tabata + weight training (Tabata, 2020), and Tabata training is claimed can increase muscle performance (Mcrae et al., 2012). The results of previous studies indicate the potential of high-intensity exercise (90\% of MHR) for 12 weeks that can be an effective approach to improve components of physical fitness that is lower-body muscle, upper-body muscle (Hurst et al., 2019). The results of this study are supported by previous studies that prove that Tabata training may be an effective exercise modality to influence muscle strength (Blue et al., 2018; Sculthorpe et al., 2017). A similar increase occurred in another physical fitness component, muscular endurance, this is because the 12-week research program from Tabata weight training with a total of 33 sessions was enough to increase muscular endurance athletes. Previous studies also showed that HIIT/Tabata can be used to improve $\mathrm{VO}_{2 \max }$ and other muscular endurance aspects (Menz et al., 2019). Another component of physical fitness that increases the impact of the application of Tabata is flexibility. The results of this study are consistent with previous studies that showed Tabata training for 8 weeks resulted in increased flexibility of hamstring muscles (Rýzková et al., 2018).

The $\mathrm{VO}_{2 \max }$ endurance component is one of the most important elements for athletes to ensure success in training sessions or in the competition (Astorino et al., 2012). In this study, the endurance component has been shown the positive increase of the impact of the Tabata weight training program with a high intensity of 70-90\%. For increasing $\mathrm{VO}_{2 \max }$ endurance, generally supportive periods of exercise at high $\mathrm{VO}_{2 \max }$ levels (above 90\%) (Rønnestad et al., 2014). Other studies have proven Tabata training to be an effective training method in improving cardiorespiratory fitness (maximal oxygen consumption) (Astorino et al., 2012). Usually the increase in endurance is caused by the use of classical endurance training methods, such as running, bicycle training (Tabata, 2020) and rowing (Buckley et al., 2015). But currently, Tabata training induces an improvement in the aerobic system at the same level as traditional endurance training, but with the added benefit of improving muscle performance (Buckley et al., 2015). Four minutes of Tabata training (eg, burpees, jumping jacks, Mt. Climber) is performed four times per week for four weeks, resulting in a similar increase in $\mathrm{VO}_{2 \max }$ endurance (Mcrae et al., 2012). One of the Tabata research in 2019 reported that Tabata training for 6-12 weeks increased the body's $\mathrm{VO}_{2 \max }$ endurance by $9.2-15.0 \%$ and maximal accumulated oxygen deficit (MAOD) by 20.9-35.0\%. Thus, Tabata weight training is proven to be an effective method for increasing $\mathrm{VO}_{2 \text { max }}$ endurance components.

Our study found that the power component had a positive increase caused by Tabata weight training 3 times a week for 12 weeks. Research (Fajrin et al., 2017) applied that Tabata in plyometric form for 6 weeks showed a significant increase in power. Increased power occurs because of anaerobic activity of the glycolysis enzyme in skeletal muscle increases after Tabata training (Domaradzki et al., 2020). We confirm that 12 weeks Tabata training program significantly increases fitness component. The previous author also emphasized that Tabata training appeared as a method that can improve the fitness component (Martínezlópez et al., 2018).

\section{The Effects of Circuit Weight Training for Physical Fitness}

The results of the Circuit Weight training intervention showed an increase in muscle strength in the legs and arms. The results of this study are in line with previous studies that Circuit training can increase muscle strength (Marcos-Pardo et al., 2019; Jung et al., 2019). Furthermoe, Circuit training with the addition of weight training is claimed to be an effective exercise to increase aerobic capacity, muscle strength and endurance (Cardozo et al., 2019). The increase is due to the Circuit training using a high variation exercise program such as consecutive exercises for upper and lower body muscles (e.g. diamond push-ups, pull ups, 
squat jumps) (Lehnert et al., 2015). Circuit training has become an effective training strategy to promote strength so that it increases (Mayorga-Vega et al., 2013).

In this study we found that Circuit weight training can improve muscular endurance in martial arts athletes. This finding is supported by previous studies (Mayorga-Vega et al., 2013). Circuit training programs such as dumbbells, diamond push-ups with loads on the arm, Lunges with body weight, squat jumps or having a weight training system are important mechanisms for increasing muscular endurance (Arazi \& Asadi, 2012).

We confirm that Circuit Weight training can significantly increase flexibility. A study conducted in Korea on flexibility shows that the Circuit is the main capital to increase flexibility in obese Female, it is because in the Circuit implements high training intensity and frequency of aerobic exercise drills (Kim et al., 2018). Kang and Lee (2012) also reported the same results that the effects of circuit weight training for 12 weeks effectively increased flexibility.

Another finding in this study is the effective Circuit weight training program to increase the $\mathrm{VO}_{2 \max }$ endurance component Sonchan, Moungmee, and Sootmongkol (2017) found that after 8 weeks of the Circuit training program, anaerobic capacity and cardiovascular endurance significantly increased $(P<0,05)($ Birkett et al., 2019).

Power is an important element for pencak silat athletes to produce hard and fast blows, through this research power can be increased after Circuit weight training intervention 3 times a week for 12 weeks. Previous studies state that frequency in the Circuit training program resulting in a significant increase in muscle power (Romero-arenas et al., 2013). Thus, the Circuit weight training program can be used as a guide to improve the physical fitness component. The results of this study are supported by previous researchers that the Circuit training for 7 weeks in the Army in Switzerland was significantly able to improve the physical fitness of the soldiers (Hofstetter et al., 2012). The latest finding in this study is that Tabata weight training is superior in improving components, such as $\mathrm{VO}_{2 m a x}$ endurance, power and flexibility. While Circuit weight training is superior in increasing components related to muscle strength and muscular endurance.

\section{CONCLUSION}

Tabata and Circuit training by adding weight training, both have proven to be effective in increasing the physical fitness component of Female pencak silat athletes. In addition, the results of this study can be evidence that Tabata and Circuit weight training is one of the fun training for martial arts athletes in the current era. Although the physical fitness component has increased the impact of the Tabata intervention and circuit weight training, there are still limitations in this study, sampel this study used athletes only one gender (female), further study need to be performed with more athletes and add other training, such as Fartlek, Zumba.

\section{REFERENCES}

Ahmad, A. M. (2019). Moderate-intensity continuous training: is it as good as high-intensity interval training for glycemic control in type 2 diabetes?. Journal of Exercise Rehabilitation, 15(2), 327-333. https://doi.org/10.12965/jer.1836648.324

Akınoğlu, B., \& Kocahan, T. (2018). Comparison of muscular strength and balance in athletes with visual impairment and hearing impairment. Journal of Exercise Rehabilitation, 14(5), 765-770. https://doi.org/10.12965/jer.1836304.152

Arazi, H., \& Asadi, A. (2012). Multiple Sets Resistance Training: Effects of Condensed versus Circuit Models on Muscular Strength, Endurance and Body Composition. Journal of Human Sport and Exercise, 7(4), 733-740. https://doi.org/10.4100/jhse.2012.74.01 
Astorino, T. A., Allen, R. P., Roberson, D. W., \& Jurancich, M. (2012). Effect of high-intensity interval training on cardiovascular function, VO2max, and muscular force. The Journal of Strength \& Conditioning Research, 26(1), 138-145. https://doi.org/10.1519/JSC.0b013e318218dd77

Batacan Jr, R. B., Duncan, M. J., Dalbo, V. J., Tucker, P. S \& Fenning, A. S. (2017). Effects of highintensity interval training on cardiometabolic health: a systematic review and meta-analysis of intervention studies. British journal of sports medicine, 51(6), 494-503. http://dx.doi.org/10.1136/bjsports-2015-095841

Birkett, S. T., Nichols, S., Sawrey, R., Gleadall-Siddall, D., McGregor, G \& Ingle, L. (2019). The effects of low-volume high-intensity interval training and circuit training on maximal oxygen uptake. Sport sciences for health, 15(2), 443-451. https://doi.org/10.1007/s11332-019-00552-2

Blue, M., Smith-Ryan, A. E., Trexler, E. T., \& Hirsch, K. R. (2018). The effects of high intensity interval training on muscle size and quality in overweight and obese adults. Journal of Science and Medicine in Sport, 21(2), 207-212. https://doi.org/10.1016/j.jsams.2017.06.001

Buckley, S., Knapp, K., Lackie, A., Lewry, C., Horvey, K., Benko, C., Trinh, J., \& Butcher, S. (2015). Multimodal high-intensity interval training increases muscle function and metabolic performance in females. Applied Physiology, Nutrition, and Metabolism, 40(11), 1157-1162. https://doi.org/10.1139/apnm-2015-0238

Cardozo, D. C., DE Salles, B. F., Mannarino, P., Vasconcelos, A., Miranda, H., Willardson, J. M., \& Simão, R. (2019). The Effect of Exercise Order in Circuit Training on Muscular Strength and Functional Fitness in Older Women. International Journal of Exercise Science, 12(4), 657.

Domaradzki, J., Cichy, I., Rokita, A., \& Popowczak, M. (2020). Effects of Tabata Training During Physical Education Classes on Body Composition, Aerobic Capacity, and Anaerobic Performance of Under, Normal and Overweight Adolescents. International Journal of Environmental Research and Public Health, 17(3), 876. https://doi.org/10.3390/ijerph17030876

Fajrin, F., Kusnanik, N.W \& Wijono. (2017). Effects of High Intensity Interval Training on Increasing Explosive Power, Speed, and Agility. In Journal of Physics: Conference Series (Vol. 947, No. 1, p. 012045). IOP Publishing.

Foster, C., Farland, C. V., Guidotti, F., Harbin, M., Roberts, B., Schuette, J., Tuuri, A., Doberstein, S. T., \& Porcari, J. P. (2015). The Effects of High Intensity Interval Training vs Steady State Training on Aerobic and Anaerobic Capacity. Journal Of Sports Science \& Medicine, 14(4), 747-755.

Gaya, A.R., Mello, J.B., Dias, A.F., Brand, C., Cardoso, V.D., Nagorny, G.A.K., Mota, J., García-Hermoso, A., \& Gaya, A.C.A. (2019). Temporal trends in physical fitness and obesity among Brazilian children and adolescents between 2008 and 2014. Journal of Human Sport and Exercise, 15(3), 549-558. https://doi.org/10.14198/jhse.2020.153.07

Gerosa-Neto, J., Antunes, B. M., Campos, E. Z., Rodrigues, J., Ferrari, G. D., Rosa Neto, J. C., Bueno, C. R., Junior, \& Lira, F. S. (2016). Impact of long-term high-intensity interval and moderate-intensity continuous training on subclinical inflammation in overweight/obese adults. Journal of Exercise Rehabilitation, 12(6), 575. https://doi.org/10.12965/jer.1632770.385 
Greenlee, T. A., Greene, D. R., Ward, N. J., Reeser, G. E., Allen, C. M., Baumgartner, N. W., Cohen, N. J., Kramer, A. F., Hillman, C. H., \& Barbey, A. K. (2017). Effectiveness of a 16-Week High-Intensity Cardioresistance Training Program in Adults. Journal of Strength and Conditioning Research, 31(9), 2528. https://doi.org/10.1519/JSC.0000000000001976

Hurst, C., Weston, K.L. \& Weston, M. (2019). The effect of 12 weeks of combined upper- and lower-body high-intensity interval training on muscular and cardiorespiratory fitness in older adults. Aging Clinical and Experimental Research, 31(5), 661-671. https://doi.org/10.1007/s40520-018-1015-9

Hofstetter, M., Maeder, U., \& Wyss, T. (2012). Effects of a 7 Week Outdoor Circuit Training Program on Swiss Army Recruits. The Journal of Strength \& Conditioning Research, 26(12), 3418-3425. https://doi.org/10.1519/JSC.0b013e318245bebe

Imanudin, I \& Sultoni, K. (2017). Tabata Training for Increasing Aerobic Capacity. In IOP Conference Series: Materials Science and Engineering (Vol. 180, No. 1, p. 012205). IOP Publishing.

Ingle, L., Sleap, M., \& Tolfrey, K. (2006). The effect of a complex training and detraining programme on selected strength and power variables in early pubertal boys. Journal of Sports Sciences, 24(9), 987997. https://doi.org/10.1080/02640410500457117

Joo, C. H. (2015). Development of a non-damaging high-intensity intermittent running protocol. Journal of Exercise Rehabilitation, 11(2), 112. https://doi.org/10.12965/jer.15195

Jung, W. S., Kim, Y. Y., \& Park, H. Y. (2019). Circuit Training Improvements in Korean Women with Sarcopenia. Perceptual and Motor Skills, 126(5):828-842. https://doi.org/10.1177/0031512519860637

Jumareng, H., Setiawan, E., Patah, I. A., Aryani, M., Asmuddin., \& Gani, R. A. (2021). Online Learning and Platforms Favored in Physical Education Class during COVID-19 Era: Exploring Student' Perceptions. International Journal of Human Movement and Sports Sciences, 9(1), 11 - 18.

Kang, H., Lee, Y.S., Park, D., \& Kang, D. (2012). Effects of 12-week circuit weight training and aerobic exercise on body composition, physical fitness, and pulse wave velocity in obese collegiate women. Soft Computing, 16(3), 403-410. https://doi.org/10.1007/s00500-011-0724-1

Kartomi, M. (2011). Traditional and Modern Forms of Pencak Silat in Indonesia: The Suku Mamak in Riau. Musicology Australia, 33(1), 47-68. https://doi.org/10.1080/08145857.2011.580716

Kim, K. H., \& Lee, H. B. (2019). Effects of circuit training interventions on bone metabolism markers and bone density of old women with osteopenia. Journal of exercise rehabilitation, 15(2), 302. https://doi.org/10.12965/jer.1836640.320

Kim, J. W., Ko, Y. C., Seo, T. B., \& Kim, Y. P. (2018). Effect of circuit training on body composition, physical fitness, and metabolic syndrome risk factors in obese female college students. Journal of Exercise Rehabilitation, 14(3), 460. https://doi.org/10.12965/jer.1836194.097

Khammassi, M., Ouerghi, N., Hadj-Taieb, S., Feki, M., Thivel, D., \& Bouassida, A. (2018). Impact of a 12week high-intensity interval training without caloric restriction on body composition and lipid profile in sedentary healthy overweight/obese youth. Journal of Exercise Rehabilitation, 14(1), 118. https://doi.org/10.12965/jer.1835124.562 
Lee, M. K., Kim, N. K., \& Jeon, J. Y. (2018). Effect of the 6-week home-based exercise program on physical activity level and physical fitness in colorectal cancer survivors : A randomized controlled pilot study. Plos One, 13(4), 1-10. https://doi.org/10.1371/journal.pone.0196220

Lehnert, M., Stastny, P., Sigmund, M., Xaverova, Z., Hubnerova, B \& Kostrzewa, M. (2015). The effect of combined machine and body weight circuit training for women on muscle strength and body composition. Journal of Physical Education and Sport, 15(3), 561.

Marcos-Pardo, P.J., Orquin-Castrillón, F.J., Gea-García, G.M. (2019). Effects of a moderate-to-high intensity resistance circuit training on fat mass, functional capacity, muscular strength, and quality of life in elderly: A randomized controlled trial. Scientific Reports, 9(1), 1-12.

Martínez-lópez, E.J., Torre-Cruz, M. J. D. L., Suárez-Manzano, S., Ruiz-Ariza, A. (2018). Original Article 24 sessions of monitored cooperative high-intensity interval training improves attention-concentration and mathematical calculation in secondary school. Journal of Physical Education and Sport, 18(3), $1572-1582$.

Mayorga-Vega, D., Viciana, J \& Cocca, A. (2013). Effects of a Circuit Training Program on Muscular and Cardiovascular Effects of a Circuit Training Program on Muscular and Cardiovascular Endurance and their Maintenance in Schoolchildren. Journal of Human Kinetics,37(1), 153-160. https://doi.org/10.2478/hukin-2013-0036

Menz, V., Marterer, N., Amin, S. B., Faulhaber, M., Hansen, A. B., \& Lawley, J. S. (2019). Functional Vs. Running Low-Volume High-Intensity Interval Training: Effects on VO2max and Muscular Endurance. Journal of Sports Science \& Medicine, 18(3), 497-504.

McRae, G., Payne, A., Zelt, J. G., Scribbans, T. D., Jung, M. E., Little, J. P., \& Gurd, B. J. (2012). Extremely low volume, whole-body aerobic-resistance training improves aerobic fitness and muscular endurance in females. Applied Physiology, Nutrition, and Metabolism,37(6), 1124-1131. https://doi.org/10.1139/h2012-093

Nugroho, A. (2020). Analisis Penilaian Prestasi Teknik Dalam Pertandingan Pencak Silat. Jorpres (Jurnal Olahraga Prestasi), 16(2), 66-71. https://doi.org/10.21831/jorpres.v16i2.31655

Plevková, L \& Peráčková, P. (2019). The Effects of A 6-Week Strength And Endurance Circuit Training on Body Image of High School Girls. Facultatis Educationis Physicae Universitatis Comenianae, 59(2), 184-192. https://doi.org/10.2478/afepuc-2019-0016

Romero-Arenas, S., Martínez-Pascual, M., \& Alcaraz, P. E. (2013). Impact of resistance circuit training on neuromuscular, cardiorespiratory and body composition adaptations in the elderly. Aging and Disease, 4(5), 256-263. https://doi.org/10.14336/AD.2013.0400256

Rønnestad, B. R., Hansen, J., Vegge, G., Tønnessen, E., \& Slettaløkken, G. (2015). Short intervals induce superior training adaptations compared with long intervals in cyclists - an effort-matched approach. Scandinavian journal of medicine \& science in sports, 25(2), 143-151. https://doi.org/10.1111/sms.12165

Roth, A., Schmidt, S. C. E., Hartmann, S., Scharenberg, S., Altmann, S., Jekauc, D., \& Bös, K. (2019). Development of physical fitness consideration of talent-specific aspects under. Journal of Human Sport and Exercise, 15(3), 1-15. 
Rubín, L., Suchomel, A., Cuberek, R., Dušková, L., \& Tláskalová, M. (2017). Self-assessment of physical fitness in adolescents. Journal of Human Sport and Exercise, 12(1), 219-235.

Rýzková, E., Labudová, J., Grznár, L \& Šmída, M. (2018). Effects of aquafitness with high intensity interval training on physical fitness. Journal of Physical Education and Sport, 18, 373-381.

Saputra, M. Y., Mulyana, Komarudin \& H Sartono. (2017). Optimization of Pencak Silat Athletes Coordination Through Brain Jogging. In IOP Conference Series: Materials Science and Engineering (Vol. 180, No. 1, p. 012216). IOP Publishing.

Setiawan, S., Iwandana, D. T., Festiawan, R, \& Baptista, C. (2020). Improving handball athletes' physical fitness components through Tabata training during the outbreak of COVID-19. Jurnal SPORTIF: Jurnal Penelitian Pembelajaran, 6(2), 375-389. https://doi.org/10.29407/jsunpgri.v6i2.14347

Setiawan, E., Budiarto., \& Afriyuandi, A. R. (2020). Korelasi Antara Physical Activity dan Physical Fitness Pada Atlet Bolabasket Level Pemula. Jurnal Pendidikan Olahraga. 9(2), 197-208. https://doi.org/10.31571/jpo.v9i2.2005.

Sculthorpe, N. F., Herbert, P., \& Grace, F. (2017). One session of high-intensity interval training (HIIT) every 5 days, improves muscle power but not static balance in lifelong sedentary ageing men: A randomized controlled trial. Med, 96(6), e6040. https://doi.org/10.1097/MD.0000000000006040

Sonchan, W., Moungmee, P., \& Sootmongkol, A. (2017). The Effects of a Circuit Training Program on Muscle Strength, Agility, Anaerobic Performance and Cardiovascular Endurance. International Journal of Medical, Health, Biomedical, Bioengineering and Pharmaceutical Engineering, 11(4), 170173.

Sumpena, A., \& Sidik, D. J. (2017). The impact of tabata protocol to increase the anaerobic and aerobic capacity. In IOP Conference Series: Materials Science and Engineering (Vol. 180, No. 1, p. 012189). IOP Publishing.

Tabata, I. (2020). Tabata training: one of the most energetically effective high - intensity intermittent training methods. The Journal of Physiological Sciences, 69(4), 559-572.

Tack, C. (2013). Evidence-Based Guidelines for Strength and Conditioning in Mixed Martial Arts. Strength \& Conditioning Journal, 35(5), 79-92. https://doi.org/10.1519/SSC.0b013e3182a62fef

Vassilis, S., Yiannis, M., Athanasios, M., Dimitrios, M., Ioannis, G., \& Thomas, M. (2019). Effect of a 4week detraining period followed by a 4-week strength program on isokinetic strength in elite youth soccer players. Journal of Exercise Rehabilitation, 15(1), 67-73.

Wilke, J., Kaiser, S., Niederer, D., Kalo, K., Engeroff, T., Morath, C., Vogt, L., \& Banzer, W. (2019). Effects of high-intensity functional circuit training on motor function and sport motivation in healthy, inactive adults. Scandinavian journal of medicine \& science in sports, 29(1), 144-153. https://doi.org/10.1111/sms.13313

Yadav, M., \& Sardar, S. (2018). Effect of Circuit Weight Training on Physical Fitness Variables of Gorakhpur University Football Players. International Journal of Physical Education and Sports, 2(12), 25-29. 